\title{
Ecological Citizenship and Democracy: Communitarian versus Agonistic Perspectives
}

\section{Anneleen Kenis*}

Department of Earth and Environmental Sciences, KU Leuven, Belgium

* Email: Anneleen.Kenis@ees.kuleuven.be.

Postal address: Anneleen Kenis, Department of Earth and Environmental Sciences, KU Leuven, Celestijnenlaan 200E - bus 2409, 3001 Heverlee, Belgium.

This is a post-print version of an article which appeared in Environmental Politics. Check the following website for the published version:

http://www.tandfonline.com/doi/full/10.1080/09644016.2016.1203524

\begin{abstract}
Grassroots environmental movements have recently started to question the focus on sustainable consumption as a main strategy to tackle climate change. They prefer to address individuals as citizens rather than as consumers, and focus on collective rather than individual change. Two prominent movements in this regard are Transition Towns and Climate Justice Action. While both movements criticise conventional approaches, they put forward entirely different strategies for what has to happen instead. Based on extensive qualitative research, I analyse how these movements manifest themselves in Flanders (Belgium). The focus is on their different accounts of how and why collective practices have to be built, and the place they attribute to 'the political' in this. The analysis reveals the existence of two different forms of ecological citizenship: one communitarian, the other agonistic.
\end{abstract}

Keywords: Sustainable consumption; ecological citizenship; democracy; climate change; postpolitics; the political; Transition Towns; Climate Justice Action

\section{Introduction}

In the first handbook published by the Transition Towns movement, founder Rob Hopkins (2008b) drew a clear distinction between conventional environmentalism and the Transition approach. Whereas conventional environmentalism focuses on 'individual behaviour', uses 'fear, guilt and shock as drivers for action', and prescribes what people should do to tackle climate change (such as campaigns urging people to buy FSC-labelled wood, or to change their driving style), Transition Towns focuses on 'group behaviour', uses 'hope, optimism and 
proactivity as drivers for action' and aims 'to act as [a] catalyst[s] for a community to explore and come up with its own answers' (Hopkins, 2008 b, p. 135).

The discourse of the movement thus resonates with the growing critique in academic literature of the omnipresence of sustainable consumption in green thinking. Critical scholars target the individualisation, moralisation and commodification characteristic of conventional environmental discourses, which would conceal the structural character of the environmental crisis, shifting responsibility to households and individuals who, through market incentives or in a moralist fashion, are urged to change their individual (often consumer) behaviour (Clover 2002, Courtenay-Hall and Rogers 2002, Jensen 2002, Jensen and Schnack 2006).

Here, I aim to understand the different types of environmental commitment that are promoted in the discourses of environmental movements and in academic literature. I do this in particular from the viewpoint of theories of the (post-) political as developed by authors such as Chantal Mouffe (2006), Jacques Rancière (1999) and Slavoj Žižek (2000). On this basis, I aim to shed new light on the distinction between the predominant sustainable consumption framework and a more comprehensive ecological citizenship perspective. As I will show, the latter category covers widely different approaches. Despite a similar critique of conventional frameworks, new grassroots environmental movements differ in their visions of what should happen instead. To illustrate this divergence, I will compare how Transition Towns and the Climate Justice Action movement give shape to ecological citizenship. ${ }^{1}$

Like Transition Towns, the grassroots climate movement Climate Justice Action criticises the fact that many conventional environmental campaigns approach people as objects rather than as subjects of change and advocate individual instead of collective change. However, as I will argue, the movements differ greatly in how they conceive of the collectivity, the 'we' they want to build to take common action. Crucially, the extent to which this 'we' is represented in political terms is a key point of divergence. As a result, two different forms of ecological citizenship can be distinguished: a communitarian and an agonistic one. Importantly, this distinction not only renders intelligible the differences that exist between types of ecological engagement, but also allows to grasp how people inscribe themselves within a broader (post)political constellation.

My analysis relies, on the one hand, upon post-foundational political theory (in particular, the work of Chantal Mouffe (1992b, 2002, 2006)) which provides a critical theoretical account of the political-historical context within which the debate on sustainable 
consumption and ecological citizenship can be situated, even though Mouffe did not directly address these topics herself. On the other hand, the analysis is based on extensive qualitative research carried out over several years in both Transition Towns and Climate Justice Action movements. I not only investigated how members of both movements conceive of their own engagement, but also, more importantly, how they perceive the type of environmental commitment promoted by movements of which they are not a part. The combination of this theoretical framework and empirical material allows us to better understand the ways in which people try to move beyond an individualised and depoliticised way of dealing with climate change and the difficulties they are confronted with in this endeavour.

\section{Theoretical background}

\section{Sustainable consumption and post-politics}

A vast literature has been produced on changing individual behaviour as a strategy to tackle environmental problems such as climate change. Hundreds of studies have been undertaken during recent decades to gain better understanding of why and when people change their individual (consumer) behaviour (Bamberg and Möser 2007, DEFRA 2008, Heimlich and Ardoin 2008, Jackson 2005, Kollmuss and Agyeman 2002, Rickinson 2001, Stevenson and Keehn 2006).

At the same time, this approach increasingly has been called into question: many scholars have shown how the focus on sustainable consumption tends to downplay the complexity of current environmental problems and their structural anchorage in our society and ways of living (Courtenay-Hall and Rogers 2002, Jensen 2002). It is also criticised for leading to the privatisation of environmental action (Clover 2002, Courtenay-Hall and Rogers 2002, Maniates 2001), making people's engagement conditional upon their purchasing power (Courtenay-Hall and Rogers 2002, p. 289) and approaching individuals as objects rather than as potential subjects of change (Jensen and Schnack 2006).

A large part of the behaviour change literature studies how individuals' (consumer) behaviour can be steered via economic incentives (Berglund and Matti 2006), nudging (Ölander and Thøgersen 2014) or via non-rational means such as role models, social pressure or by connecting the desired behaviour to positive feelings of freedom, friendship or sex, as is done in the advertising industry (Heimlich and Ardoin 2008, Jackson 2005, McKenzie-Mohr and Smith 1999). This approach often starts from a kind of behaviourism which does not consider people 
as conscious citizens (Jensen and Schnack 2006). At best, people are conceived as conscious consumers, but even that is not always the case.

Looking from the perspective of theories of post-politics or depoliticisation (Mouffe 2006, Rancière 1999, Žižek 2000), one could state that a post-political construction of engagement is underpinning a large part of the contemporary environmental debate (Swyngedouw 2007, 2010, Kenis and Lievens 2014). This construction does not only 'address and construct citizens as consumers or purchasers of commodities' (Dowling 2010, p. 491), but also presupposes new forms of steering, controlling and disciplining them (Kenis and Mathijs 2012). Steering happens, for example, via advertising campaigns, which are supposed to work upon people's unconscious drives, or via economic incentives. As Andrew Dobson and Derek Bell (2006b, p. 1) argue, the predominant idea is that '[i]f the sticks and carrots are appropriately placed and priced, self-interested rational actors [...] will be induced to push their own appropriate behavioural buttons without further government intervention'. They conclude that ' $[i]$ t is this last aspect of the scheme that makes it so enticing for liberal-capitalist governments.'

The paradox of such a post-political construction is that it inevitably has important political effects on the strategic field of environmentalism, although it does not acknowledge these effects nor confront them head-on. It hides what is politically at stake in environmental action behind an individualising, economic, moral or even psychological discourse. Indeed, the focus on sustainable consumption is not only a product of the currently predominant neoliberal paradigm, it also reinforces this paradigm by depicting environmental problems in purely market and/or moralistic terms. A key dimension of this approach is to reduce people to consumers rather than to call upon them to act as citizens. 'It is symptomatic of the triumph of the ultimate neoliberal subject - the citizen-consumer - that people in the affluent world have internalized the idea that the best way to tackle climate change is through lifestyle change' (MacGregor 2014, p. 624).

Exactly this attempt to realise change within the parameters of what currently exists is characteristic of current post-political tendencies with regard to climate change. In its strongest form, it entails the idea that mere technological changes will suffice, and no further social change is therefore needed. At best, a very weak form of social change is advocated, namely behaviour change. The related reduction of society to the simple sum of individuals, the identification of individuals as mere consumers, and the reduction of environmental 
transformation to changing individual purchasing acts, are symptomatic for and reinforce the post-political tendencies present in the environmental sphere. Such a discourse fails to represent society in political terms, namely as characterised by power, hegemony, exclusion and conflict (Mouffe 2000, 2006). It conceals the fact that environmental commitment will inevitably be confronted with deeply political questions, such as what kind of socioenvironmental future we are striving for, how to get there, and who could be possible allies and opponents in this endeavour.

\section{Ecological citizenship}

In order to move beyond the limits of the sustainable consumption approach, the discussion on ecological citizenship provides a good starting point. As Andrew Dobson and Ángel Valencia Sáiz (2005, p. 157) have argued, a 'turn to citizenship' in the literature on environmental politics led to a wide debate on the notion of ecological citizenship (e.g., Dobson 2006, Dobson and Bell 2006a, Gabrielson 2008, Hayward 2006). Admittedly, some scholars have used the term 'citizenship' to refer mainly to the responsibilities of ecologically aware individuals, sometimes almost identifying citizens as consumers (e.g. Seyfang 2005, 2006; Spaargaren and Mol 2013). Ecological citizenship then refers to a conscious choice to change one's individual behaviour, rejecting practices whereby this behaviour is steered through economic stimuli or advertisement campaigns. In other words, the aim is to change the motivational basis underlying environmental action. As Dobson and Sáiz (2005, p. 157) argue, ecological citizenship requires 'shifts in attitudes at a deep level - deeper than those reached by fiscal measures.'

Dobson refers in this context to the notion of the ecological footprint, which can help inform citizens' decisions. However, as Amanda Machin (2012, p. 853) notices, 'for Dobson, the obligations that arise from the ecological footprint apply to the individual, not to a collective'. Machin is right in the sense that moving beyond a post-political framework requires paying attention to the social-economic structures and power mechanisms which characterise our current socio-environmental predicament (Kenis and Lievens 2015), and thus to the collective side of engagement. Realising structural change will be difficult if one remains within the contours of an individualising representation of the environmental field. As Mouffe (1992b) stresses, genuine political action happens when people act together with others in common actions to realise transformational change. As she argues, one cannot think of citizenship 
outside of its relation with the political and the democratic public sphere: citizenship is 'the democratic political identity par excellence' (Mouffe 1992b, p. 6). Interestingly, Mouffe adds a term to the notion of citizenship: she emphasises the necessity of its democratic character. The formation of collectivities is not necessarily political as such: the existence of a democratic, plural space where different collectivities can confront each other in struggle and debate is a necessary condition for the explicit recognition of their political nature. A key question is thus how environmental movements construct collective identities and how we can conceptualise the notions of citizenship that underpin them.

\section{Research design}

In order to develop this conceptual discussion in an empirically grounded way, I engaged for one and a half years in activist research intensively studying the rise of Transition Towns and Climate Justice Action in Flanders (Belgium) from the inside (Hale 2008). Subsequently, I turned to a less intensive engagement, following the further evolutions of the movements from a short distance. Over four years, I actively took part in more than 80 meetings, activities and actions, conducted semi-structured in-depth interviews with 40 persons who were very actively involved in one or both movements, and performed a document analysis of books, leaflets and websites. $^{2}$

Whereas the data collected on the basis of activist involvement and document analysis form the background of the study, the interviews, which were analysed in detail using the software program NVIVO ${ }^{\circledR}$, provide the 'hard' data. The interviews consisted of three parts. First, I started with open questions concerning the interviewee's own activity, including questions about the relation between her/his own engagement and more conventional approaches in environmentalism. Second, I presented 12 theses drawn from publications by the movement in which the respective interviewee was involved, asking whether s/he agreed with these theses or not, and why. Third, I asked each interviewee to read a short text produced from text fragments of the other movement, and comment on it. This allowed me to investigate how s/he defines her/his own activity in relation to alternative forms of engagement. In other words, it enabled me to study the specific way in which the relations between 'we' and 'they' are understood in both movements.

\section{Research findings}


In what follows, I will first describe the emergence of both movements, their relation to conventional approaches, and their establishment of a more comprehensive account of ecological citizenship. Second, I will show that the movements' conceptions of ecological citizenship differ significantly, the key difference concerning how the movements conceive of the ' $w e^{\prime}$, the collective level of their engagement. Third, I will argue that this difference closely relates to the place both movements attribute to 'the political.'

\section{Moving beyond sustainable consumption}

\section{Transition Towns}

Transition Towns originated in the UK in 2005 as a reaction to the lack of appropriate action to tackle peak oil and climate change (Brangwyn and Hopkin 2008, Hopkins 2008b). The movement is sceptical of both the predominant focus on sustainable consumption and the idea that we should wait and hope for more far-reaching government initiatives. The crucial ingredient of their project is therefore situated on a collective level: the building of resilient communities (Bailey, Hopkins and Wilson 2010, Kenis and Mathijs 2014a, Neal 2013, North 2010). To quote Ben Brangwyn, one of the pioneers of the movement: 'If we wait for governments, it'll be too late; if we act as individuals, it'll be too little; but if we act as communities, maybe it'll be enough' (Irving 2009). Interestingly, even participants' psychological motivation is addressed within a collective framework. For instance, it is recommended to set up 'heart \& soul working groups' within every Transition initiative, in which people can investigate together how to overcome personal barriers towards change (Hopkins 2008b, p. 87). ${ }^{3}$

Interestingly, it is not the case that individual behaviour change is considered unimportant. Rather, '[g]iven that purely personal lifestyle change is insufficient, the scale of the local community is identified as the most effective level at which to organise' (North 2010, p. 1588). Still, at this point an ambiguity sometimes sneaks into Transition Towns' discourse. Stating that 'the creation of the problems of peak oil and climate change is the result of many individual actions', and that 'the solution requires taking responsibility for these actions' (Hopkins 2008b, p. 92), an individualising analysis of environmental problems co-exists with a community approach. 


\section{Climate Justice Action}

Climate Justice Action was established even more explicitly on the basis of disappointments with conventional environmental approaches. ${ }^{4}$ Its argument is not only that insufficient action is undertaken to tackle climate change, but especially that many of the proposed measures are 'false solutions' because they do not really tackle climate change, or shift the crisis onto other socio-ecological terrains. The movement rejects these measures (e.g. nuclear energy, emissions trading and agro-fuels) as 'neoliberal illusions' and calls upon people to 'join together in taking control over our lives and real solutions'. Real solutions include community control over natural resources, food sovereignty, settling the North's ecological debt to the South, and a 'just transition' to a low-carbon economy (CJA booklet 2009, p. 1). Climate Justice Action stresses these 'solutions from below will not come without a struggle' (CJA booklet 2009, p. 24), and such a struggle can only be won if people organise themselves collectively.

Interestingly, the reason why more people do not engage in collective action is blamed on capitalist consumer culture. As Derrick Jensen (2009, p. 26) argues: 'Part of the problem is that we've been victims of a campaign of systematic misdirection. Consumer culture and the capitalist mindset have taught us to substitute acts of personal consumption (or enlightenment) for organised political resistance'. Though most of its activists make farreaching sustainable choices in their personal lives, they resolutely reject changing individual (consumer) behaviour as a strategy because 'personal change does not equal political change' (Jensen 2009, p. 26). The reduction of individuals to consumers is explicitly denounced since a focus on individual change 'accepts capitalism's redefinition of us from citizens to consumers'. It is argued that ' $[b] y$ accepting this redefinition, we reduce our potential forms of resistance to consuming and not consuming. Citizens have a much wider range of available resistance tactics, including voting, not voting, running for office, pamphleting, boycotting, organising, lobbying, protesting.'

\section{Breaking with conventional environmental approaches}

Conceiving of people as actors who consciously and collectively attempt to tackle climate change, the discourses of both Transition Towns and Climate Justice Action go beyond a narrow focus on sustainable consumption and advocate a form of ecological citizenship (see figure 1). Admittedly, only the Climate Justice Action movement explicitly uses the term 'citizenship'. Yet, 
in the way Transition Towns frames people's engagement as part of a common endeavour that goes beyond the private sphere, the concept, if not the word, is a key part of its outlook. The choice to move beyond a focus on sustainable consumption also resonates in the statements of many of their participants. As Erika, who is active in Transition Towns, explains: 5 'the first thing that attracted me in the movement is that it is a completely different approach than the conventional environmental movement, which after all ... always focuses on your own behaviour and norms'. Similarly, Kate argues:

There is a very strong focus on individual behaviour change, and I don't think that this is always the most motivating choice for people. I think... well, that you should simply go for more communal solutions [...] that you take distance from the individualisation of those problems and that you move towards the collective, to 'how we can tackle it together'? That, instead of buying energy saving lamps, you realise something bigger together.

Several interviewees dismissed the blaming character of discourses of changing individual (consumer) behaviour, stressing the structural embeddedness of individual choices, rejecting the marketisation of environmental solutions, and underlining that more profound change is needed. As Jean-Francois, a climate justice activist, states:

It's not that individual behaviour change is not important, but I still have some second thoughts about it. Because the solutions are not individual. They can only be collective. And I think this stress on individual responsibility, that this is sometimes very blaming.

Interestingly, this does not mean that these 'Transitioners' and climate justice activists are against individual behaviour change. Rather, they seem to find it self-evident to try to live as sustainably as possible, but they at the same time point to the limits of this approach. As Gregory explains:

Well, eh, I am actually in favour of individual behaviour change, and I think that it is necessary; I also do it myself. But I think it is a totally unproductive and counterproductive strategy to believe that this is a miraculous solution, that this will solve climate change. I even think there will be resistance by people against such strategies. [...] Individuals are in this way also reduced to market subjects, consumers. 
They are made responsible for climate change, and at the same time the real, structural causes disappear out of sight.

[Figure 1 near here]

\section{Two conceptions of ecological citizenship}

Both movements thus move beyond the conventional sustainable consumption approach, by promoting key elements of what can be called ecological citizenship. At the same time they transcend a limited approach to ecological citizenship which merely focuses on the conscious motivation underlying behaviour change. Indeed, for both movements the collective dimension is key, and a crucial question is therefore how this collective dimension is framed. In other words, how do Transition Towns and Climate Justice Action understand the community, the 'we', within which ecological citizens are embedded? While they share the stress on this collective dimension, how they frame the latter will radically set both movements apart.

In what follows, I will discuss five basic tenets of the type of collectivity the movements aim to build (see figure 2). I will investigate how the movements define the boundaries of their collectivity, how they conceive of the social relations within the collective, and between the community and society at large, where they situate the motor of change and how the common good is understood. As I will argue, these divergent conceptions of the 'we' within which ecological citizens are embedded correspond to the place they attribute to the political.

[Figure 2 near here]

To start with, how do the movements define the boundaries of the community or collectivity they want to build? This question is easily answered for Transition Towns: the movement tries to organise people on the basis of 'the local scale' and frames the collectivity unambiguously as a geographical entity (Kenis and Mathijs 2014a). Both the focus on the 'local' and 'scale' are important in this. As William argues: 'I think you should work locally, actually simply because that is a scale on which you can get some grip. And finally, because it is the scale on which you live your life.' One of the advantages of organising on the basis of 'scale' would be that it allows movement beyond the circle of people who are 'already convinced'. As Kate explains: 
What attracts me is that it has the potential to go beyond one's own circle. Because you work on the level of a neighbourhood or village, you actually work geographically instead of thematically ... which means you try to reach out to all people who live in a certain area, and you try to do things together.

In correspondence with this, Transitioners distance themselves from activist groups that organise on a more political basis. As Seth states:

The problem with many activist movements is that they make insufficient effort to involve the broader, local population. [...] In this sense, Transition has a much bigger potential, I think. Because you really work locally. And many activist movements don't do that.

One such activist group is Climate Justice Action. While most Transitioners are not generally negative about it, they consider the movement as having a problem in this regard, and see this as one of the reasons they would never become active in it. John explains:

The objection I have against such movements is that you sit around the table with a specific group of people who all agree with each other. Well, I don't think I would get involved in this ... because I think you will be only there with likeminded people [...] It will surely be interesting and fun, but I prefer to invest my energy in people who actually live here and try to do something.

The differences that Transitioners bring to the fore are significant. The type of collectivity that Climate Justice Action aims to build is indeed of a completely different nature. It is explicitly a deterritorialised collective, based on an alliance of people - throughout places - who have $a$ common political project for society. As is stated in one of its outreach texts: 'we are reaching out to all those who share our vision' (CJA 2009). Furthermore, the 'we' they want to establish is explicitly defined in opposition to a common adversary, a 'them'.

Interestingly, even modest or cautious manifestations of this agonistic approach evoke negative reactions from Transitioners. The very first sentences of one of Climate Justice Action's leaflets already triggered critical responses from Transitioners. Sarah reads the text aloud: "'Once again, those who created the problem claim they also have the solutions: carbon 
trading, so-called 'clean coal', nuclear energy, biofuels, even a 'green new deal'. These are not real solutions."'. She sighs:

'(t)hose who created the problem?': Yeah, that is exactly the type of we/them reasoning which we try to react against. Moreover, all solutions which are now put forward are dismissed. That appeals to few people, if you always state 'this is wrong', and 'even the solution is wrong'. Fine with me if you want to take a critical stance, but you have to know that you will never reach many people in this way. Like this, you discourage people from the very beginning.

Sarah is not the only Transitioner who is convinced that an agonistic approach will 'discourage people' or 'scare them off', and that this is one of the big problems that confront movements such as Climate Justice Action. As Marc states about Climate Justice Action:

I think they are too extreme for mainstream people [...] You know, with such an approach you will always have allies and adversaries, while Transition Towns does not look for allies and adversaries. Eh ..., of course they look for allies. But not adversaries [laughs].

Seth summarises the differences between Climate Justice Action and Transition Towns by stating: 'it simply doesn't help to shout against your neighbour because he works for ExxonMobil, you know?'

Unsurprisingly, these differences also have an influence on how both movements conceive of the social relations within the collectivity. We/them distinctions are explicitly rejected in many Transition Towns texts. For instance, the Transition Handbook states: 'Lesson One [is] Avoid "Them and Us"' (Hopkins, 2008b, p. 125). The movement emphasises the need to build better social ties and this is considered to be difficult in a conflictual atmosphere. As Anna explains: 'you experience it yourself when people talk to you, as if you are the enemy, so to speak. That will not facilitate cooperation... The openness is gone.' Jacob motivates his choice for the Transition Towns movement as follows:

What is nice about Transition is [...] that it is not blaming others and thinking in dualities of 'we-them', since that is a false duality. [...] The whole mentality of struggle is left 
behind. You observe it yourself: when you approach people in the right way, they are very receptive.

Dialogue and the creation of better social relations are thus considered crucial, in the first instance to build the local community, but also to enhance society's resilience, and even to tackle climate change. Inclusion, collaboration and dialogue are put forward as alternatives to a more agonistic approach. In the words of Hopkins (2008a):

One fundamental misunderstanding [...] is the belief that change is something that we have to fight for, that those in positions of power will cling to business as usual for as long as possible, that globalisation will only wobble if we shake it hard enough.

Transitioner Sophie fully agrees with this statement, arguing:

In the end, [companies] also have an interest in saving the earth. Moreover, their system... you already see that the money system... it falls apart and they are also duped. That's why I don't believe that it is all so contradictory and irreconcilable.

Exactly those elements about which many Transitioners are so enthusiastic meet fierce reactions amongst climate justice activists. Alexis says: 'I don't see why it would be a misunderstanding if you state that you have to fight for change.' And Timothy reacts: 'Yes, of course people in positions of power will react enthusiastically [to Transition discourse]. Because it doesn't threaten their positions at all [...] Those people in power positions aren't stupid.' And he adds: 'Actually, I think the concentration of power is one of the main reasons things are going wrong today.' Jean-Francois reads out loud: "'Transition is determinedly inclusive and non-blaming $[\ldots]^{\prime \prime \prime}$ :

Yeah, that sounds good. But does it work like that? Well, history is made through struggle. Sometimes there is simply a we and a them. From time to time, I like reading a novel in which someone from the oppressive class turns out to have a complex and interesting personality with which you can feel sympathy. But historically, it is someone who needs to be put aside. There are unequal positions of power .... I can't stand it. For me, exactly this denial reproduces existing inequalities. And that's where it starts. Making this invisible. 
After having given a similar reply, Alice calls out: 'Does that really come out of the Transition Handbook? It's really dangerous actually.'

Unsurprisingly, Climate Justice Action starts from a very different point of view. Precisely because society constitutes an unavoidably conflict-laden and contested space, it is argued that first and foremost one has to understand the power relations that are at work and that prevent more effective and democratic steps to tackle climate change from being taken. Subsequently, one has to organise collectively in order to build enough counter-power to challenge these oppressive structures. In other words, it is about building a 'we' that is strong enough to tackle 'them'. However, in their turn, Transitioners strongly criticise this approach. As Anna states:

But do you know what's the danger? That kind of movement acts very often from a perspective of struggle. [...] It's all about 'we 'versus 'the others'. It's all about 'the others will be against us'. Yes, I think this is a pointless strategy.

Sophie explains that this was one of the main reasons why she chose Transition Towns: 'The nice thing about Transition is that it is, in my feeling, entirely different. Not denouncing, not fighting, but trying to change by oneself.' Similarly, Dave emphasises the importance of a 'positive story', of not being 'anti' all the time. Still, after a short silence, he adds: 'of course, by being in favour of something, you are also against something else.'

Significantly, some Transitioners even went a step further in their doubt whether or not a conflictless approach is tenable. As Sarah, for instance, muses:

Yes, I agree that we should not indicate culprits... Provisionally not. I think, if we become successful, then we'll evidently get quarrels with people who have interests that it doesn't happen, and then we will notice whether there is no 'we-and-them' [laughs].

Interestingly, the assumption of Climate Justice Action that structurally embedded power relations are a central issue is viewed as not only valid for society at large, but also for localities, and even for their own communities. In their view, all collectivities are conflict-laden and contested spaces. As Jason explains:

Even if you try to work prefiguratively, you remain in a certain sense a mirror of society, that cannot be excluded. There are differences, between men and women for example. 
$[\ldots]$ and even in the ideal society [...] power will play a role in every social relation to a certain extent.

While climate justice activists assume that power relations will always continue to exist, they nevertheless try to overcome them as much as possible in their own communities. For instance, in order to avoid the power of representatives in a classic democratic system, they developed a form of direct democracy through consensus decision making. In a passionate way, Jason explains:

But why am I in favour of consensus decision making? For a simple reason: majority votes do not seek the best solution, but the solution which finds a majority of half plus one. Regardless of whether that majority has a lot of interest in the issue at stake, while the harm might be very big for the minority. Consensus is about seeking a way with which everyone can feel comfortable.

Still, as several climate justice activists point out, even in such a political community, power relations remain. Although consensus-seeking is 'the best one can get' according to most activists, it is seen as far from perfect. Kelly comments: 'Yeah, it's double, because on the one hand you think there's democracy, but on the other the biggest mouths get to speak most. [...] Well, I find that it does not always look so democratic.' And Alice similarly notices: 'I sometimes have the impression that people who are quite dominant and know very well what they want and are verbally strong, out-argue others too easily'. She stares in front of herself for a few seconds, and adds: 'but perhaps this is the case everywhere.'

Remarkably, the way Climate Justice Action consciously inserts itself in a conflictual setting in society at large thus contrasts with how it deals with internal power relations. Whereas external power relations should be made visible and be politicised through an outspokenly agonistic approach, internal power relations should be transcended through deliberation and consensus-seeking. To realise this, or at least to come as close as possible, specific tools are developed each time inequalities and power relations pop up. As Jason illustrates: 'There are systems such as vibeswatch, these are also imperfect, but still, they try to be attentive for questions such as "can people express themselves"? Sometimes people are inhibited from speaking out.' 
At the same time, however, consensus decision-making is considered as something that is only feasible or desirable within the confines of an already established political community. Jason again: 'A basic condition for seeking consensus is that there is, eh, a common goal, a kind of common ground. [...] You presuppose a kind of general interest which binds everyone'. Consensus on 'the common good' is thus sought within the framework of a self-conscious project for hegemony, which is clearly delineated from its opponents.

Transition Towns, in contrast, aims to find a consensus about the 'common good' within the local community, a community which actually already exists within a geographical circumscription, and which needs to be rediscovered and even reinvented, including the reinvention of local traditions, crafts and customs. Their hope and assumption is that if dialogue is facilitated in an open atmosphere amongst people living in the same area, people can learn to look beyond the confines of their own (political) background and perspectives, and arrive at a common vision of the good that is shared by all local inhabitants.

The notion of the 'common good', or 'the good life', is very important in Transition Towns discourse, even if it is not explicitly mentioned in official documents. These notions articulate the future vision Transition Towns is striving for. As Anna tells: 'Yes, it's all about concrete translations, suggestions for how it could look ... then I actually see the good life. And I find that very attractive.' Similarly, William ponders:

I hope we'll manage to understand that one can still live a beautiful life by looking for alternatives in what is not material, in a form of the good life, which is interesting, agreeable, perhaps social but essentially based on less oil.

A key step in a transition process is therefore constituted by common visioning exercises in which local inhabitants imagine what a future, localised community life could look like. However, while these exercises are framed as open-ended, and participants are encouraged to think outside the box, they are at the same time explicitly encouraged to come up with future alternatives that radically break with current 'oil dependent' and 'anonymous' ways of living, and which thus constitute key elements of what Transition Towns conceives as the good life (see also Kenis and Mathijs 2014a).

We are thus confronted with two diverging understandings of the common good. On the one hand, Transition Towns assumes that it is possible to define a common good that is shared by everyone (or at least, by all inhabitants of a particular place). The condition of 
possibility of this shared definition of the common good is (a particular kind of) deliberation. On the other hand, Climate Justice Action also develops a notion of the common good, albeit one which is supposedly only shared within a particular political community. That it can lead to disagreement (and conflict) within society is explicitly stated. It is a common good that distinguishes itself from and is defined in relation to other common goods, defended by other political forces. As I will argue in the next section, this brings us close to Mouffe's notion of radical or agonistic democracy, whereby different political forces propose '[their] own interpretation of the "common good", and [thereby try] to implement a different form of hegemony' (Mouffe, 2000, p. 104).

\section{The place of 'the political'}

Interestingly, Mouffe (1992b) suggests a distinction between three types of citizenship: liberalism, civic republicanism (of which communitarianism is a part), and agonism. Whereas liberalism rejects the notion of the common good in favour of notions of the right and justice, both communitarianism and Mouffe's own agonistic approach maintain a central place for the common good. The latter two approaches differ, however, in that for the communitarian perspective, the community is based on a 'substantive idea of the common good' that threatens to take a 'dangerous conservative turn', according to Mouffe (1992b p. 227). In contrast, for the agonistic viewpoint, there is also a notion of the common good, but its content is less substantial and, most importantly, it is presented as contestable.

Transferring Mouffe's ideas onto the ecological terrain, Machin (2013) draws a similar distinction between a green republican and a radical democratic or agonistic approach. On the one hand, she sympathises with the fact that green republicanism does not regard individuals 'as self-interested consumers but rather as responsible and virtuous citizens' (p. 4), and that 'acknowledges the importance of community in underpinning a green way of life' (p. 3). On the other hand, she critically diagnoses green republicanism as presupposing 'an agreement upon the substantive content of the "common good"' (p. 4). As she critically wonders: '[w]ho decides the meaning and demands of the "common good"?"

According to Machin, a similar diagnosis can be made of green deliberative approaches, which, despite their claims to the contrary, do suppose the possibility of an overarching common good. However, this time the common good is something that has to be arrived at through active participation and dialogue. As she argues: 'It is simply expected that citizens will 
reach an agreement that a sustainable way of life is in the common good and, further, they will reach agreement on what this way of life looks like. No consideration is given to the possibility that there may be those who are left out of the discussion and that there may be those who don't agree' (Machin, 2013, p. 58).

The ambiguity of the visioning exercises conducted by Transition Towns is very similar. On the one hand, these exercises are meant to be open-ended, and the common good is presented as something one has to arrive at together through dialogue. On the other hand, the basic tenets of this common good are predefined. Transition Towns stands on two legs: a communitarian ideal of the good life; and a deliberative approach to consensus-seeking, whereby deliberation is expected to (re)produce this ideal, allowing for small variations.

In a certain way this closure of the deliberative process is unavoidable. As Machin (2013) argues, at the moment one adds 'green' to the notions of republicanism and deliberation, the dialogue is never completely open anymore. This should not be a problem as such. The problem resides in the fact that it is assumed that everyone can agree on this premise; and that open dialogue will lead to this conclusion. The need to tackle climate change and to do that by building resilient local communities is thus taken for granted. The problem is not only that exclusions due to the specific way the common good is framed and implemented are misrecognised, but also that these exclusions can barely be contested or addressed within an atmosphere that is so strongly oriented to inclusion and consensus. This explains part of the depoliticised character of Transition Towns: the non-neutral but political nature of the common good and how it is constructed threaten to remain unacknowledged, as a result of which it remains outside of the sphere of debate and contestation.

The difficulty the Transition Towns movement has in dealing with conflicts lends support to Machin's (2013) argument that such forms of green republicanism and green deliberative notions of democracy do not take pluralism sufficiently seriously. By supposing that through far-going dialogue one can arrive at consensus, one threatens to misrecognise the fundamental and ineffaceable presence of power and conflict (see also Mouffe 1992b, 2006). By adding a predefined notion of the common good, the possibility of pluralism and more fundamental disagreement is further erased. Machin's (2013, p. 47) indictment that the presupposition of one overarching common good is 'antithetical to pluralism' is probably too strong when talking of Transition Towns. Yet, Transition Towns' understanding of pluralism appears to be based on the existence of a plurality of local communities. Therefore, its vision remains imbued with a 
kind of communitarianism which fails to fully acknowledge the potential political conflicts following from pluralism. Mouffe (1992a, p. 29) argues that she

cannot accept the solution put forward by the communitarians, for their attempt to recreate a type of Gemeinschaft community cemented by a substantive idea of the common good is [...] incompatible with the pluralism that is constitutive of modern democracy.

Climate Justice Action, in contrast, radicalises this pluralism and thinks of it in terms of real conflicts and oppositions. That is why I consider Climate Justice Action close to an agonistic conception of citizenship. As Mouffe (1992b, p. 231) argues, an agonistic approach 'does not postulate the existence of a substantive common good', but 'nevertheless implies the idea of commonality, of an ethico-political bond that creates a linkage among the participants in the association, allowing us to speak of a political "community" even if it is not in the strong sense'. This bond is a public concern, based on a specific interpretation of principles such as equality and liberty, which remains contestable. The common bond can be understood differently by different hegemonic projects, which entails there will always remain the potential for conflict about the meaning of this common bond.

Strikingly, however, Climate Justice Action integrates an element of deliberative democracy in its preference for internal consensus decision-making, which brings it somewhat closer to Transition Towns again. This ambiguity reveals the difficulties encountered when implementing a radical democratic vision for a nascent social-ecological movement. On the one hand, this movement intends to engage in agonistic struggle, while on the other hand, it wants to integrate a large group of activists into a coherent political collective through deliberative means.

Crucial for my story is the different types of 'we' that result. The difference between Transition Towns and Climate Justice Action is a difference between a communitarian 'we' and an agonistic 'we.' This distinction corresponds with two types of citizen commitment which require people to inscribe themselves very differently within a collectivity. Transition Towns' mode of inscription is consensual, deliberative, but with a strong stress on emotional and psychological dimensions, and directed towards all inhabitants of the local community. Climate Justice Action's inscription is based on a common adversary and a deliberative process of 
deciding upon political principles, within the confines of a common political fault line. The result is two different kinds of ecological citizenship: one communitarian, the other agonistic.

\section{Conclusion}

At the outset, I argued that in contemporary society there is a strong 'post-political' hegemony in the way environmental problems, such as climate change, are framed. The focus on sustainable consumption bears the hallmark of this post-political hegemony. Both Transition Towns and Climate Justice Action question and contest it by offering people new forms of engagement beyond their status as consumers. To a certain extent, they both re-open and repoliticise the debate on climate change. However, from this initial similarity onwards, their paths quickly diverge.

To clarify what is precisely at stake, it is useful to distinguish politicisation on the level of the individual and on the level of a community. In the first case, politicisation occurs when people no longer view themselves as mere consumers (or clients, or in terms of other strictly private roles), but (also) as citizens who have the capacity to publicly participate in shaping society. Politicisation on the level of the individual therefore refers to the shift from sustainable consumer to ecological citizen. Both movements studied here facilitate and promote this move, even though Transition Towns does not explicitly frame this shift in terms of a move towards citizenship.

Politicisation on the level of the community has a slightly different character. It takes place when this community is capable of viewing itself as part of a broader context of social, economic and political relations, which it understands to be characterised by power and conflict, and in which it self-consciously inserts itself. At stake is therefore how a community frames the place it adopts in the public sphere and the collective dimension of the kind of ecological citizenship it advocates. The movements studied here choose divergent paths in this regard. Transition Towns tends to think of itself as a geographical community, internally harmonious and externally related to similar local communities. Climate Justice Action, by contrast, depicts society explicitly in conflictual terms and self-consciously inserts itself into this conflictual setting. Parallel to these two forms of collective organisation, I have therefore distinguished two forms of ecological citizenship: communitarian and agonistic. The extent to which the resulting ' $w e^{\prime}$ is politicised is therefore also radically different: whereas Transition 
Towns' notion of 'we' is strongly depoliticising, Climate Justice Action adopts an outspokenly (perhaps overly?) politicised view of collective identity.

But how do these 'we's' concretely establish themselves? As Mouffe (2006, p. 15) states: 'in the field of collective identities, we are always dealing with the creation of a "we" which can exist only by the demarcation of a "they"'. Interestingly, both movements seem to develop their own identity at least partly by distancing themselves from the other. Both the strong reactions to statements of the other movement, and the fact that many respondents found it easier to explain their disagreement with the other movement than to justify their own approach, confirm this observation. The specificity of both forms of ecological citizenship therefore manifests itself most clearly when explicitly confronted with an alternative, which shows that the politicisation of their mutual relations helps clarify what is at stake in each of them.

\section{Notes}

\footnotetext{
${ }^{1}$ In 2016, there is a tendency no longer to speak about Transition Towns, but about Transition culture or Transition network (see also Mason and Whitehead 2012). However, at the time this research was conducted, the term 'Transition Towns' was still predominantly used, at least in Flanders.

${ }^{2}$ For more information on the specificities of the case studies and the methodologies used, see Kenis (2015).

${ }^{3}$ For a more comprehensive account of the main features of the Transition Towns movement, see amongst others Bailey, Hopkins and Wilson (2010), Barry and Quilley (2009), and Smith (2011).

${ }^{4}$ For more information on the Climate Justice Action movement, see amongst others Featherstone (2013), Chatterton, Featherstone and Routledge (2013), and Kenis and Mathijs (2014b).

${ }^{5}$ All first names refer to interviewees of one of both movements. These names have been modified to ensure anonymity.
}

\section{References}

Baarda, B., De Goede, M., and Teunissen, J., 2005. Basisboek Kwalitatief Onderzoek:

Handleiding voor het opzetten en uitvoeren van kwalitatief onderzoek. Groningen/Houten:

Wolters-Noordhoff.

Bailey, I.G., Hopkins, R. and Wilson, G.A., 2010. Some things old, some things new: The spatial representations and politics of change of the peak oil relocalisation movement, Geoforum, 41 (4), 595-605. 
Bamberg, S. and Möser, G., 2007. Twenty years after Hines, Hungerford, and Tomera: A new meta-analysis of psycho-social determinants of pro-environmental behaviour, Journal of Environmental Psychology, 27, 14-25.

Barry, J. and Quilley, S., 2009. Transition Towns: 'Survival', 'Resilience' and Sustainable Communities: Outline of a Research Agenda, Ecopolitics Online, 1 (2), 14-37.

Berglund, C. and Matti, S., 2006. Citizen and consumer: the dual role of individuals in environmental policy. Environmental Politics, 15 (4), 550-571.

Brangwyn, B. and Hopkins, R., 2008. Transition initiatives primer: becoming a transition town, city, district, village, community or even island. Devon: Transition Network.

CJA, 2009. Call: Climate Action Camp.

Clover, D., 2002. Traversing the Gap: concientización, educative-activism in environmental adult education, Environmental Education Research, 8 (3), 315-323.

Courtenay-Hall, P. and Rogers, L., 2002. Gaps in Mind: problems in environmental knowledgebehaviour modelling research, Environmental Education Research, 8 (3), 283-297. DEFRA, 2008. A framework for pro-environmental behaviours. London: DEFRA. Dobson, A., 2006. Ecological citizenship: a Defence, Environmental Politics, 15 (3), 447 - 451. Dobson, A. and Bell, D., 2006a. Environmental Citizenship, London: The MIT Press. Dobson, A. and Bell, D., 2006b. Introduction. In: A. Dobson and D. Bell, eds. Environmental Citizenship. London: MIT Press.

Dobson, A. and Sáiz, Á.V., 2005. Introduction, Environmental Politics, 14 (2), 157 - 162.

Dowling, R., 2010. Geographies of identity: climate change, governmentality and activism, Progress in Human Geography, 34 (4), 488-495.

Gabrielson, T., 2008. Green citizenship: a review and critique, Environmental Politics, 12 (4), 429-446.

Hale, C.R., 2008. Engaging Contradictions: Theory, Politics, and Methods of Activist Scholarship. Berkeley: University of California Press.

Hayward, T., 2006. Ecological citizenship: a rejoinder, Environmental Politics, 15 (3), 452-453. Heimlich, J.E. and Ardoin, M.N., 2008. Understanding behavior to understand behavior change: a literature review, Environmental Education Research, 14 (3), 215 - 237. Hopkins, R., 2008a. "The Rocky Road to a Real Transition": A Review, Transition Culture, http://transitionculture.org/2008/05/15/the-rocky-road-to-a-real-transition-by-paulchatterton-and-alice-cutler-a-review/. 
Hopkins, R., 2008b. The Transition Handbook. From oil dependency to local resilience. Devon: Green Books.

Irving, S. 2009. Transitional demands. Red Pepper [online]. Available from:

http://www.redpepper.org.uk/Transitional-demands/ [Accessed 18 April 2016].

Jackson, T., 2005. Motivating Sustainable Consumption. A review of evidence on consumer behaviour and behavioural change. Surrey: SDRN.

Jensen, B.B., 2002. Knowledge, Action and Pro-environmental Behaviour, Environmental Education Research, 8 (3), 325-334.

Jensen, B.B. and Schnack, K., 2006. The action competence approach in environmental education, Environmental Education Research, 12 (3-4), 471-486.

Jensen, D., 2009. Forget shorter showers. Why personal change does not equal political change. In: COP15zine, ed. Dealing with distractions. Confronting Green Capitalism in Copenhagen \& Beyond.

Kenis, A. 2015. From Individual to Collective Change and Beyond. Ecological Citizenship and Politicisation. Unpublished thesis (PhD). University of Leuven.

Kenis, A. and Lievens, M. 2014. Searching for 'the political' in environmental politics. Environmental Politics, 23 (4), 531-548.

Kenis, A. and Lievens, M. 2015. The Limits of the Green Economy. From re-inventing capitalism to re-politicising the present, London: Routledge.

Kenis, A. and Mathijs, E. 2012. Beyond individual behaviour change: the role of power, knowledge and strategy in tackling climate change. Environmental Education Research, 18 (1), 45-65.

Kenis, A. and Mathijs, E. 2014a. (De)politicising the local: The case of the Transition Towns movement in Flanders (Belgium). Journal of Rural Studies, 34, 172-183.

Kenis, A. and Mathijs, E. 2014b. Climate change and post-politics: Repoliticising the present by imagining the future? Geoforum, 52, 148-156.

Kollmuss, A. and Agyeman, J., 2002. Mind the Gap: why do people act environmentally and what are the barriers to pro-environmental behavior? Environmental Education Research, 8 (3), 239-260.

MacGregor, S., 2014. Only Resist: Feminist Ecological Citizenship and the Post-politics of Climate Change, Hypatia, 29 (3), 617-633. 
Machin, A., 2012. Decisions, disagreement and responsibility: towards an agonistic green citizenship, Environmental Politics, 21 (6), 847-863.

Machin, A., 2013. Negotiating climate change. Radical democracy and the illusion of consensus, London: Zed Books.

Maniates, M.F., 2001. Individualization: Plant a Tree, Buy a Bike, Save the World? Global Environmental Politics, 1 (3), 31-52.

Mason, K. and Whitehead, M., 2012. Transition urbanism and the contested politics of ethical place making, Antipode, 44 (2), 493-516.

McKenzie-Mohr, D. and Smith, W., 1999. Fostering Sustainable Behavior: an introduction to community-based social marketing. Gabriola Island: New Society Publishers.

Mouffe, C., 1992a. Citizenship and Political Identity, October, 61, 28-32.

Mouffe, C., 1992b. Dimensions of Radical Democracy. Pluralism, Citizenship, Community. London: Verso.

Mouffe, C., 2000. The Democratic Paradox. London: Verso.

Mouffe, C., 2002. Politics and passions. The stakes of democracy. London: CSD Perspectives. Mouffe, C., 2006. On the political. London: Routledge.

Neal, S., 2013. Transition culture: Politics, localities and ruralities. Journal of Rural Studies, 32, 60-69.

North, P., 2010. Eco-Localisation as a progressive response to peak oil and climate change. A sympathetic critique, Geoforum, 41 (4), 585-594.

Ölander, F. and Thøgersen, J. 2014. Informing Versus Nudging in Environmental Policy, Journal of Consumer Policy, 37 (3), 341-356.

Rancière, J., 1999. Disagreement : Politics and Philosophy. Minneapolis: University of Minnesota Press.

Rickinson, M., 2001. Learners and Learning in Environmental Education: a critical review of the evidence, Environmental Education Research, 7 (3), 208-320.

Seyfang, G., 2005. Shopping for Sustainability: Can Sustainable Consumption Promote Ecological Citizenship? Environmental Politics, 14 (2), 290-306.

Seyfang, G., 2006. Ecological citizenship and sustainable consumption: Examining local organic food networks, Journal of Rural Studies, 22, 383-395. 
Smith, A., 2011. The Transition Town Network: A Review of Current Evolutions and Renaissance, Social Movement Studies: Journal of Social, Cultural and Political Protest, 10 (1), 99-105.

Spaargaren, G. and Mol, A.P.J., 2013. Carbon flows, carbon markets, and low-carbon lifestyles: reflecting on the role of markets in climategovernance, Environmental Politics, 22 (1), 174193.

Stevenson, G. and Keehn, B., 2006. I will if you will. Towards sustainable consumption. London: SDC/NCC.

Swyngedouw, E., 2007. Impossible "Sustainability" and the Postpolitical Condition. In: R. Krueger and D. Gibbs, eds. The Sustainable Development Paradox. London: The Guilford Press. Swyngedouw, E., 2010. Apocalypse Forever? Theory, Culture \& Society, 27 (2-3), 213-232. Žižek, S., 2000. The Ticklish Subject. The Absent Centre of Political Ontology. London: Verso. 